\title{
Glycosylation changes on serum glycoproteins in ovarian cancer may contribute to disease pathogenesis
}

\author{
Radka Saldova ${ }^{\mathrm{a}}$, Mark R. Wormald ${ }^{\mathrm{b}}$, Raymond A. Dwek ${ }^{\mathrm{b}}$ Pauline M. Rudd ${ }^{\mathrm{a}, *}$ \\ ${ }^{a}$ Dublin-Oxford Glycobiology Laboratory, NIBRT, Conway Institute, UCD, Dublin, Ireland \\ ${ }^{\mathrm{b}}$ Oxford Glycobiology Institute, Department of Biochemistry, University of Oxford, Oxford, UK
}

\begin{abstract}
Ovarian cancer is the most lethal of all gynaecological cancers among women. Serum CA125 is the only biomarker that is used routinely and there is a need for further complementary biomarkers both in terms of sensitivity and specificity.

$N$-glycosylation changes in ovarian cancer serum glycoproteins include a decrease in galactosylation of $\operatorname{IgG}$ and an increase in sialyl Lewis $\mathrm{X}\left(\mathrm{SLe}^{\mathrm{x}}\right)$ on haptoglobin $\beta$-chain, $\alpha 1$-acid glycoprotein and $\alpha 1$-antichymotrypsin. These changes are also present in chronic inflammation but not in malignant melanoma, where there are low levels of inflammatory processes. Acute phase proteins carrying increased amounts of SLe ${ }^{\mathrm{x}}$ have an increased half-life. Sialylation of acute phase proteins also decreases apoptosis favouring survival of cancer cells. Cancer cells produce inflammatory cytokines which influence glycosylation processing in liver parenchymal cells. Altered glycosylation of the acute phase protein transferrin plays an important role in iron homeostasis. Glycosylated transferrin and its glycans have anti-apoptotic properties and many transferrin receptors in carcinoma could play a role in development of anaemia. Decreased galactosylation and sialylation of IgG increases the cytotoxicity of natural killer cells and complement activation via mannose-binding lectin (MBL). Altered glycosylation of acute phase proteins and IgG suggests that cancer regulates certain pathways favouring cancer cells survival.
\end{abstract}

Keywords: Ovarian cancer, $N$-linked glycans, acute-phase proteins, IgG, biomarker

\section{Introduction}

Ovarian cancer is the most lethal of all gynaecological cancers among women, according to UK cancer mortality statistics [1]. Most patients are diagnosed in an advanced stage of the disease [34]. Patients with early diagnosed ovarian cancer have a 90\% 5-yearsurvival rate, whereas in advanced stages III and IV, this decreases to $30 \%$ [34].

The majority of ovarian cancers develop on the ovarian surface [105]. Factors which increase the risk of ovarian cancer include: (i) More years of ovulation (no

* Corresponding author: Pauline M. Rudd, Dublin-Oxford Glycobiology Laboratory, NIBRT, Conway Institute, UCD, Dublin 4, Ireland. Tel: +353 1716 6728; Fax: +353 1716 6950; E-mail: pauline.rudd@nibrt.ie. children, no usage of contraceptive pills, early menarche and late menopause); (ii) Inflammation of the reproductive organs; (iii) Talc and asbestos exposure; (iv) Endometriosis [96]; (v) A family history of ovarian, breast (mutation of genes BRCA1 and BRCA2) or other gynaecological cancer; (vi) For a small percentage of patients, colon cancer [78]; (vii) Use of oestrogen for more than 10 years after the menopause in hormone replacement therapy [111].

Ovarian cancer is usually diagnosed by ultrasonography, the serum biomarker CA125 or a combination of both [34]. CA125 is currently the best marker for ovarian cancer. It is elevated in $80-90 \%$ of ovarian cancer patients and the level correlates with the stage of the disease. However, CA125 is not reliable for detecting early stage cancers. It is also higher in non-mucinous tumours than in mucinous ones and can lead to a false positive response in benign conditions, pregnancy and 

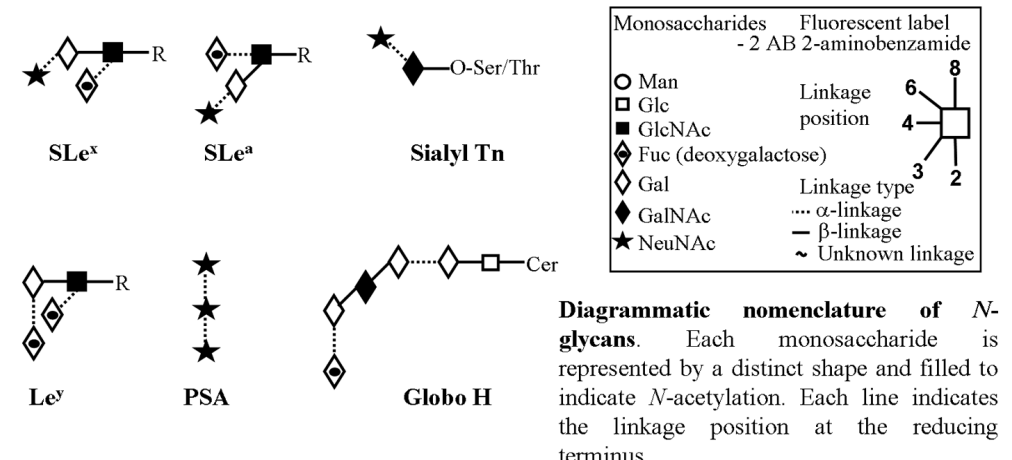

Fig. 1. Tumour antigens - sialyl Lewis $\mathrm{x}\left(\mathrm{SLe}^{\mathrm{x}}\right)$, sialyl Lewis a $\left(\mathrm{SLe}^{\mathrm{a}}\right)$, sialyl Tn, Lewis y (Le $\left.{ }^{\mathrm{y}}\right)$, polysialic acid (PSA) and globo H [149] $\mathrm{R}$ indicates where carbohydrate is linked to the polypeptide chain and Cer is where carbohydrate is linked to the glycolipid chain.

other cancers [34]. CA125 is elevated in most advanced adenocarcinomas, especially those with distant metastases e.g. breast, lung, endometrial, cervix, fallopian tube, and pancreatic [34]. CA125 is also elevated in chronic pancreatitis [50] but not in sepsis [103].

Therefore, additional biomarkers are required for this lethal cancer to complement CA125. Several other potential markers include tissue polypeptide specific antigen (TPS), lysophosphatic acid, inhibin, kallikreins, macrophage-colony-stimulating factor (M-CSF) and OVX1 [13,34]. In addition, proteomics-based approaches may be useful in discovering new ovarian cancer biomarkers $[3,16,69,146]$.

Changes in glycosylation of the acute phase proteins haptoglobin, $\alpha 1$-antitrypsin [131] alpha 2-macroglobulin, transferrin [62] and IgG [44] have been reported in ovarian cancer. Furthermore, glycosylated forms of eosinophil-derived neurotoxin and C-terminal peptides from osteopontin are elevated in ovarian cancer patients [146].

\section{Changes in glycosylation in cancer}

Changes in glycosylation occur in immune deficiency, cancer and autoimmune diseases. In cancer this includes under- and over-expression of naturally occurring glycans and also neoexpression of glycans, normally restricted to embryonic tissues [33]. These structures are mostly derived from changes in the expression levels of glycosyltranferases in the Golgi compartment of cancerous cells [33]. Changes in glycosyltransferase levels can lead to modifications in the core structure of $N$-linked and $O$-linked glycans [33]. One of the most common changes is an increase in the size and branching of $N$-linked glycans [33]. The enzyme responsible for increased branching is $N$ acetylglucosaminyltransferase V (GlcNAc-TV), which leads to $\beta 1,6 \mathrm{GlcNAc}$ branching [32]. Increased branching creates more sites for terminal sialic acid residues and together with upregulation of sialyltransferase results in increased sialylation [68]. These changes reflect differences in expression levels of sialyltransferase and fucosyltranferases in the Golgi [33] and they correlate with advanced cancer stage, tumour progression and metastasis [68].

Also, levels of specific terminal residues are changed in cancer as a result of over-expression of some glycosyltransferases [23]. In general, there are changes in the levels of certain glycans, rather than in the processing of new structures [114]. Changes in branching and increased sialylation have also been identified in chronic inflammatory conditions [29]. As chronic inflammation is often observed in cancer [80], these glycan changes may be associated with the inflammation.

The most common terminal glycan epitopes found on glycoproteins on cancer cell surfaces are; sialyl Lewis $\mathrm{x}\left(\mathrm{SLe}^{\mathrm{x}}\right)$, sialyl Lewis a $\left(\mathrm{Le}^{\mathrm{a}}\right)$, sialyl Tn, Globo H, Lewis y and polysialic acid (PSA) $[23,48,88,119,123$, 125,132,149] (Fig. 1). Tumour metastasis is facilitated by adhesion between tumour cells and platelets in the bloodstream to remote endothelial cells [124]. The selectins (E-selectin, P-selectin and L-selectin) bind to $\mathrm{SLe}^{\mathrm{x}}$ on tumour cells and contribute to tumour-cell migration to distant tissues [93].

Notably, no change was detected in the serum glycome from malignant melanoma patients, where there are low levels of inflammatory processes [114].

\subsection{Sialyl Lewis $x$ expression in cancer}

In cancer, several changes in glycosylation have been described, including the presence of SLe ${ }^{\mathrm{x}}$ in human car- 


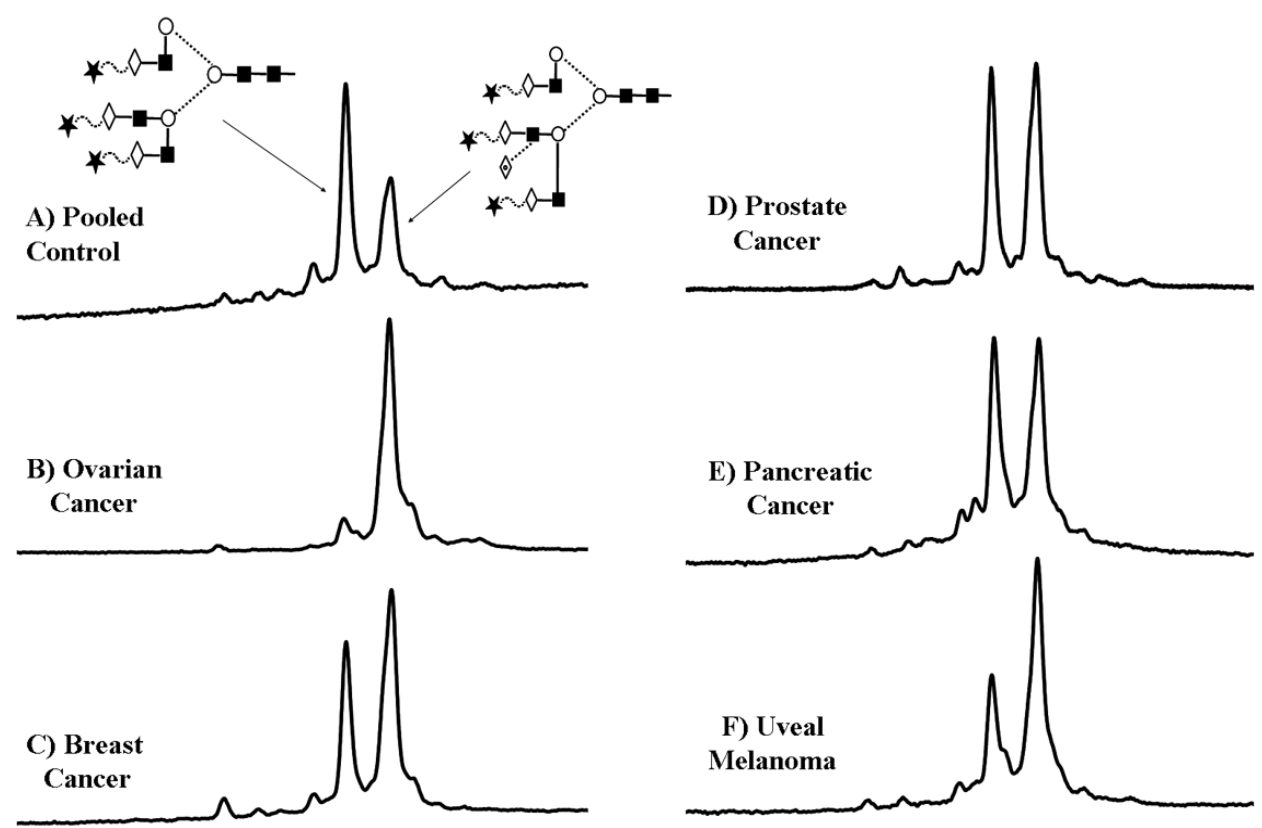

Fig. 2. Typical NPHPLC chromatograms of glycans from the trisialylated fraction previously separated by charge on WAXHPLC from A) pooled control, B) ovarian, C) breast, D) prostate, E) pancreatic and F) uveal cancer patient serum samples.

cinomas [88] (Fig. 2). The name is derived from $\mathrm{Le}^{\mathrm{x}}$, which was originally known as the X-structure [49]. $\mathrm{Le}^{\mathrm{x}}$ is a positional isomer of the Lewis blood group structure, $\mathrm{Le}^{\mathrm{a}}$ [49]. The SLe ${ }^{\mathrm{x}}$ epitope consists of a sialic acid $\alpha 2,3$ linked to galactose $\beta 1-4$ linked to GlcNAc, to which a fucose is also $\alpha 1,3$ linked. SLe $^{\mathrm{x}}$ was first described in a ganglioside fraction of human kidney [107] and trace amounts were found in human milk [142]. $\mathrm{SLe}^{\mathrm{x}}$ is also expressed on haptoglobin, $\alpha 1$-acid glycoprotein, $\alpha 1$-antichymotrypsin [22] and in neutrophilic granulocytes [39] during inflammation.

Increased levels of SLe ${ }^{\mathrm{x}}$ suggest a change in regulation of fucosyltransferases in the liver hepatocytes. To form SLe ${ }^{\mathrm{x}}$ structures, the precursor core structure has to be sialylated first and then fucosylated by $\alpha(1,3 / 1$, 4) fucosyltransferases $[8,88]$. Increased levels of SLe ${ }^{\mathrm{x}}$ correlate with decreased expression of $\alpha 1,2$ fucosyltransferase, an enzyme which competes with $\alpha 2,3$ sialyltransferase for the same substrate [9] and increased expression of $\alpha(1,3 / 1,4)$ fucosyltransferases [8,145].

\subsection{Changes in overall $N$-glycosylation in ovarian cancer serum}

Branching and sialylation increases in ovarian cancer [114]. More specific changes in ovarian cancer serum include increases in the amount of agalactosylated biantennary glycans (arising predominantly from
$\mathrm{IgG}$ ) and $\mathrm{SLe}^{\mathrm{x}}$ (from haptoglobin $\beta$-chain, $\alpha 1$-acid glycoprotein and $\alpha 1$-antichymotrypsin) [114]. These changes reflect the chronic inflammation observed in cancer. It was shown that peritoneal inflammation enhances the ovarian cancer metastatic potential [110]. Consequently, increases in levels of SLe ${ }^{\mathrm{x}}$ are not specific for cancer, as they have also been found in inflammatory conditions $[22,29,47]$. However, measuring levels of SLe ${ }^{\mathrm{x}}$ in longitudinal studies of individual patients (personalized medicine) would be beneficial to monitor progression of the disease.

Furthermore, a shift in sialic acid linkage from $\alpha 2,3$ to $\alpha 2,6$ has been observed in ovarian cancer serum glycoproteins [114]. This shift is consistent with previous findings of decreased mRNA expression of $\alpha 2,3$ sialyltransferases and increased $\alpha 2,6$ sialyltransferase in tumour tissues of ovarian cancer patients [141]. Ovarian tumour cells secrete cytokines [58,97] that can influence glycan processing in both tumour cells and surrounding tissue $[59,102]$ and may also affect the glycosylation processes of liver hepatocytes, causing shifts in serum glycoforms. This suggests that glycans from shed, secreted and on membrane glycoproteins from tumour tissue, contribute to the altered glycosylation in serum. These changes may provide insight into the cytokines to which the tumour has been exposed, since they may produce a similar shift in the glycoform populations on the tumour cells. 


\section{3. $N$-glycosylation on CA125 does not contribute to the major changes in glycan levels in ovarian cancer patient serum}

CA125 is a mucin, first detected by Bast et al. using the monoclonal antibody OC125 [14]. CA125 may be an antigen that can elicit antibody-dependent, cellmediated cytotoxicity against ovarian tumour cells. It may play a key physiological role that promotes tumour development in patients with ovarian cancer [71]. Wong et al. described CA125 major $N$-glycans on OVCAR3 cell line, which are $20 \%$ high mannose type and $80 \%$ complex type structures [71]. They are mostly mono-fucosylated bi-antennary, tri-antennary and tetra-antennary-bisected structures, with no more then one sialic acid [71]. CA125 glycans do not contribute to the major changes in glycan levels in ovarian cancer patient serum [114].

\section{Inflammation}

Inflammation is a complex defence mechanism, by which leucocytes migrate into damaged tissues to destroy the agents that can potentially cause tissue injury [40]. Acute inflammation is a limited short term response, particularly during infectious challenge, whereas, chronic inflammation is a persistent phenomenon that can lead to tissue damage [40]. In acute inflammation, initially the leukocyte infiltrate is mostly neutrophilic but after 1 to 2 days, monocytic cells predominate [40]. Chronic inflammation is associated with the presence of mononuclear cells such as macrophages and lymphocytes [40]. Cytokines play an important role in the response to inflammation [40]. Interleukin 6 (IL-6) has a dual effect; at some levels it acts as a defence mechanism but in chronic inflammation it is an inflammatory agent [40].

\section{The acute phase response leads to substantial changes in the plasma concentration of acute phase proteins}

The acute phase response, which occurs during infection, trauma, surgery, burns and inflammatory conditions, leads to substantial increases in the plasma concentration of acute-phase proteins such as C-reactive protein, serum amyloid A, haptoglobin, $\alpha 1$-acid glycoprotein, $\alpha 1$-antitrypsin, $\alpha 1$-antichymotrypsin and fibrinogen (positive acute phase proteins) or decreases in levels of albumin and transferrin (negative acute phase proteins). Two weeks following the inflammatory stimulus, the plasma concentrations of these proteins return to normal, with the exception of haptoglobin and fibrinogen, which can take three weeks to return to normal levels [41]. The chronic inflammation associated with cancer can induce an acute phase response with the same changes in the serum concentration of these proteins but these persist longer.

Cytokines are major stimulators of acute phase protein production [41]. They are produced during inflammatory processes by a variety of cells. The most important sources are macrophages and monocytes at inflammatory sites [41].

Altered glycosylation on haptoglobin, $\alpha 1$-acid glycoprotein, $\alpha 1$-antichymotrypsin and $\alpha 1$-antitrypsin in advanced ovarian cancer patient sera has been identified [114].

\subsection{Positive acute-phase proteins with altered $N$-glycosylation}

Positive acute-phase proteins increase in concentration during the acute immune response [41]. These are proteins related to the complement, coagulation and fibrinolytic systems (e.g. fibrinogen), antiproteases (e.g. $\alpha 1$-antitrypsin, $\alpha 1$-antichymotrypsin), transport proteins (e.g. haptoglobin, hemopexin), participants in inflammatory responses (e.g. secreted phospholipase $\mathrm{A}_{2}$ ) and others (C-reactive protein, serum amyloid A, $\alpha 1$-acid glycoprotein, ferritin) [41].

\subsubsection{Haptoglobin}

Haptoglobin (Hp) is a $\alpha 2$-sialoglycoprotein with haemoglobin-binding capacity, that is secreted into plasma by the liver [2,20]. The hepatic synthesis of Hp is induced by pro-inflammatory cytokines such as IL-6, IL-1 and tumour necrosis factor (TNF) [20].

$\mathrm{Hp}$ forms a complex with haemoglobin $(\mathrm{Hb})$ during haemolysis. After destruction of erythrocytes, free haemoglobin in the circulation passes through the glomerulus of the kidney. Renal damage is prevented by the binding of haemoglobin by haptoglobin. Therefore, this prevents both iron loss and kidney damage during intravascular haemolysis [45]. This acutephase protein also has bacteriostatic properties, inhibits prostaglandin synthesis and angiogenesis [75] and protects against free radicals [138].

Haptoglobin is important in iron homeostasis [138]. The identification of functional differences in haptoglobin molecules results from relatively common 
polymorphisms [138]. There are three major phenotypes: Hp 1-1, Hp 2-1 and Hp 2-2 [2,20,45].

Human haptoglobin is a tetrameric protein, composed of two $\alpha$ and two $\beta$ chains [72]. The $\beta$-chain (49 $\mathrm{kDa}$ ) is heavier than the $\alpha$-chain and is identical in all Hp types. The $\beta$ chain of Hp contains four Asn-linked glycosylation sites, all of which may be occupied [17, 72]. Glycosylation accounts for, approximately, $19 \%$ of $\beta$-haptoglobin mass [17]. Hp contains biantennary complex glycans in neutral, monosialylated and disialylated forms and triantennary complex glycans in disialylated and trisialylated forms [52].

Changes in haptoglobin glycan composition are associated with disease. Expression levels of haptoglobin $\beta$-chain increase in ovarian cancer, decrease with chemotherapy and correlate with levels of CA125 [3]. Increase in fucosylation, sialylation or branching been found in breast [46], ovarian [114,126,127], lung [53], pancreatic [98], and prostate cancers [38]. Fucose content on haptoglobin increases with tumour size [127]. Highly-sialylated Hp was found in Crohn's disease [46].

\subsection{2. $\alpha 1$-acid glycoprotein}

$\alpha$ 1-acid glycoprotein (also known as orosomucoid, AGP, Fig. 3) has a molecular weight of 41-43 kDa and is heavily glycosylated (45\%) [117]. AGP is an acute phase protein, which is synthesized mainly by hepatocytes but extrahepatic synthesis has also been reported [37]. The serum concentration of AGP rises two to five times during an acute phase response. Based on concavalin A (Con A) reactivity (ConA is mainly selective for mannosylated $N$-glycans [21]), AGP can be fractionated to ConA non-reactive, weakly reactive and strongly reactive forms.

Protein synthesis and glycosylation of AGP are independently regulated $[135,136]$, both by cytokines (mainly IL-1 and IL-6) and glucocorticoids [11,85-87]. AGP has the ability to bind and transport several basic and neutral drugs of endogenous and exogenous origin $[60,70]$. AGP has also been classified as a member of the immunocalin family, a lipocalin subfamily that modulates immune and inflammatory responses [81]. AGP stimulates cytokine secretion and thus, contributes to the inflammatory response. This effect can be enforced by the local production of AGP by monocytes in response to some of these cytokines [54]. AGP has a beneficial role in wound healing, protecting against tissue damage and is involved in the induction of non-specific resistance to infection [54].
Five $N$-glycans are attached to the human protein [147]. Each of the $N$-glycosylation sites of AGP can express any of the glycans, which can have di-, tri- or tetra-antennary structures [37]. AGP is also negatively charged ( $\mathrm{pI}$ is 2.7-3.2) due to the presence of sialic acids (12\% of total glycans) [54]. There are changes in glycosylation in inflammation such as an increase in $\mathrm{SLe}^{\mathrm{x}}$. There is a relative increase of AGP glycoforms with biantennary glycans in acute inflammation and a relative decrease of AGP glycoforms with biantennary glycans in chronic inflammation, pregnancy, estrogen administration and liver damage [29,84].

Changes in glycosylation can affect the biological properties of AGP. For instance, immunomodulatory activity of AGP depends on its glycosylation [37]. AGP, containing branched glycans, is more effective in the inhibition of lymphocyte proliferation [106], and desialylated AGP enhances inhibition of platelets aggregation [27]. Inflammation-induced increases in $\mathrm{SLe}^{\mathrm{x}}$-substituted glycans on AGP might represent a mechanism for feedback inhibition of granulocyte extravasation into inflamed tissues [37].

\subsection{3. $\alpha 1$-antichymotrypsin}

Human $\alpha 1$-antichymotrypsin is a plasma glycoprotein with a relative molecular mass of approximately $58 \mathrm{kDa}$ and carbohydrate content of $24 \%$ [74]. It is an acute phase protein, secreted by the liver which belongs to the superfamily of serpins [130]. Its concentration increases more than four-fold within a few hours in response to an inflammatory stimulus [7] and it is also elevated in cancer [64]. The physiological function of $\alpha 1$-antichymotrypsin has not yet been determined, however $\alpha 1$-antichymotrypsin inhibits chymotrypsinlike proteases [129], regulates cathepsin G activity [15], modulates the cellular functions of neutrophils [67] and lymphocytes [57] and inhibits platelet-activating-factor synthesis [25].

$\alpha 1$-antichymotrypsin has six potential glycosylation sites [112], in which disialyl bi-antennary, trisialyl tri-antennary and disialyl tri-antennary, tri- and tetraantennary glycans have been identified [73]. SLe ${ }^{\mathrm{x}} \alpha 1-$ antichymotrypsin is increased in ovarian cancer [114].

\subsubsection{Increase of positive acute phase proteins in plasma correlates with altered glycosylation}

An increase in $\mathrm{SLe}^{\mathrm{x}}$ on the haptoglobin $\beta$-chain, $\alpha 1$ acid glycoprotein and $\alpha 1$-antichymotrypsin has been observed [114]. SLe ${ }^{\mathrm{x}}$ is also present during inflammation on all these proteins [22]. 


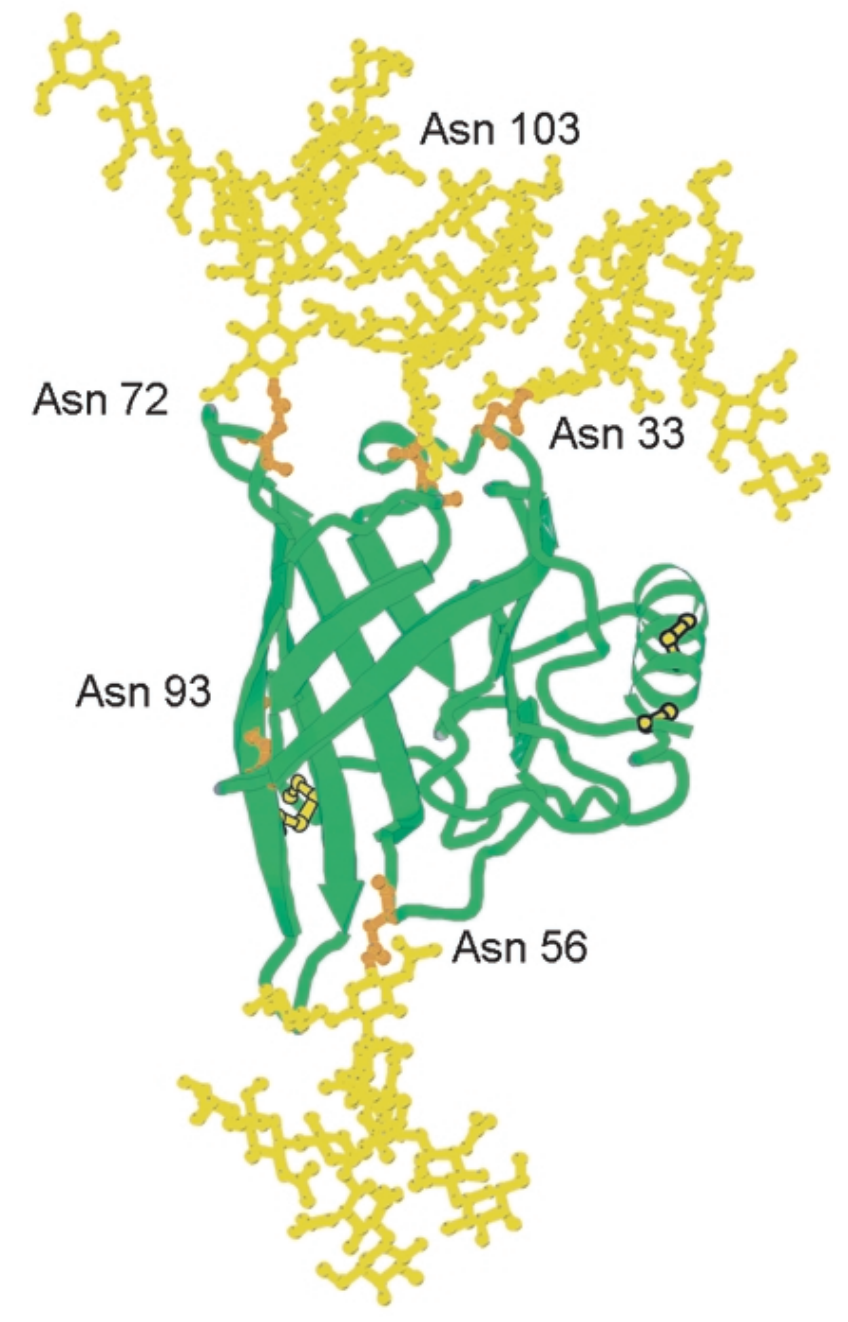

Fig. 3. Molecular model of $\alpha 1$-acid glycoprotein. The peptide fold (green) is a homology model of human alpha-1-acid glycoprotein (Pieper et al., personal communication) based on the crystal structure of chicken plasma retinol-binding protein [148]. Glycans were added to the three accessible glycosylation sites in the model (Swissprot numbering: P02763). $N$-linked glycan structures (yellow), chosen on the basis of sequencing results [147], were generated using the database of glycosidic linkage conformations [143] and in vacuo energy minimisation to relieve unfavourable steric interactions. The Asn-GlcNAc linkage conformations (Asn - orange) were based on the observed range of crystallographic values [104], the torsion angles around the Asn $\mathrm{C} \alpha-\mathrm{C} \beta$ and $\mathrm{C} \beta-\mathrm{C} \gamma$ bonds then being adjusted to eliminate unfavourable steric interactions between the glycans and the protein surface.

Terminal sialic acid and fucose on SLe ${ }^{\mathrm{x}}$ inhibits the amount of free galactose accessible to the asialoglycoprotein and Kupffer cell receptors [26] in the liver and can therefore prolong their clearance from the circulation, resulting in higher plasma concentrations [122]. The presence of $\mathrm{SLe}^{\mathrm{x}}$ glycans from haptoglobin $\beta$ chain, $\alpha 1$-antichymotrypsin and $\alpha 1$-acid glycoprotein in cancer and also in inflammation suggests that there is regulation of these acute phase protein concentrations. The biological significance of these increases is to increase their anti-apoptotic [28] and anti-inflammatory properties [35]. These anti-apoptotic properties may aid cancer metastasis. Glycosylation of these serum proteins derives from the glycosylation process during their biosynthesis in liver parenchymal cells. Inflammatory cytokines, corticosteroids and growth factors are involved in regulation of these changes [137].

\subsection{Negative acute-phase proteins with altered $N$-glycosylation}

Negative acute-phase proteins decrease in concentration during the acute immune response. These are albumin, transferrin, transthyretin and $\alpha$-fetoprotein [41]. 


\subsubsection{Transferrin}

A family of proteins, known as transferrins, control iron levels in the body [4,51]. Transferrin is present in the blood (serum transferrin), in other bodily secretions (lactoferrin), in avian egg white (ovotransferrin) and in melanotransferrin (broad range of tissue types) [139].

Transferrin is critical to protect the body from free iron in the aerobic environment of the blood and bodily fluids. Damage occurs when ferrous iron is converted to ferric iron and forms harmful free radicals. Transferrin is also involved in protection from insoluble ferric iron [140].

Additionally, serum transferrin transports iron in the blood by chelating free ferric iron from degraded haemoglobin and delivering it to cells in a receptormediated endocytotic process. While the transferrinreceptor complex is internalised, iron is released in the endosome, and the complex is recycled to the cell surface where the transferrin is released [51].

The regulation of transferrin receptor expression in various tissues is related to specific cellular iron requirements. For most non-erythroid cells, iron can regulate the transferrin receptor expression in a reciprocal manner, through modulating the stability of the receptor mRNA. Whereas, in haemoglobin-synthesizing cells, the transferrin receptor expression is independent of the cellular iron loading [82].

Serum transferrin and transferrin receptors play an important role in iron homeostasis - iron regulation in the human body. Human serum transferrin is synthesized in the liver. It is a polypeptide chain of 679 amino acid residues [12]. There are two homologous domains; the $N$-terminal and the $C$-terminal domains (with glycans attached to the $C$-terminal domain - For review see $[19,30])$. Transferrin has two glycan chains (mostly complex biantennary types, which terminate in sialic acids. The protein is fully glycosylated with these glycans present on two major Asn-linked glycosylation sites Asn 432 (Asn-Lys-Ser) and Asn 630 (Asn-ValThr) and one minor site Asn 491 (Asn-His-Cys) [116]. The glycosylation is site specific, especially, the core fucosylation, which occurs only at Asn 630 site [115]. Changes in glycosylation on transferrin can occur during disease; an increase in highly branched fucosylated glycans was reported in hepatocellular carcinoma patients [144]. However, non-glycosylated recombinant transferrin was found to be functionally indistinguishable from glycosylated serum transferrin [90,91].

\subsubsection{Altered glycosylation of the negative acute phase protein transferrin plays an important role in iron homeostasis}

The level of transferrin decreases in ovarian cancer patients' serum [3,128], in other gynaecological cancers [128] and in inflammation [108]. After chemotherapy, levels of transferrin increase or remain constant in ovarian cancer patients [3]. Glycosylated transferrin and its glycans have anti-apoptotic properties, as shown by deglycosylation, which abrogated this effect. They play an important role in regulation of the programmed cell death via alterations in cytokine expression [77]. There are many transferrin receptors present on cancer cells and this could play a role in anaemia, which is found in more than $30 \%$ of patients [42]. The transferrin receptor has three fully glycosylated sites; Asn 251, Asn-Gly-Ser; 317, Asn-His-Thr and 727, AsnGlu-Thr [24]. Glycosylation of the transferrin receptor is critical for its folding, stability and/or secretion [24, 100]. Altered glycosylation of the $N$-linked glycans of the transferrin receptor from diabetic patients leads to reduced binding affinity for transferrin [43]. Glycosylation of transferrin does not have influence on its binding capacity, but transferrin and iron uptake is reduced after transferrin deglycosylation [55].

\subsubsection{Iron homeostasis}

Formanowicz et al. [36] developed a Petri net-based model of body iron homeostasis, in which they simulated iron homeostasis, describing the homeostasis as follows:

Iron is taken from the diet. There are two forms of iron; heme iron (ferrous, $\mathrm{Fe}^{2+}$ ) and non-heme iron (ferric, $\mathrm{Fe}^{3+}$ ). Iron $\mathrm{Fe}^{3+}$ is reduced to $\mathrm{Fe}^{2+}$ in the stomach in low $\mathrm{pH}$ by reducing agents (e.g. ascorbic acid) and transported into small intestine mucous membrane. If the iron is supplemented in the $\mathrm{Fe}^{2+}$ form it is transported directly. Most of the metal in the labile iron pool in the cell is metabolically drawn into Fedependent enzymes, transported into mitochondria for heme synthesis or incorporated into ferritin for storage or detoxification. The red blood cells exist in the human body for about 120 days and after mono-nuclear cells phagocytose them. These cells are responsible for the recirculation of iron derived from red blood cells. Iron then enters the circulation, binds to transferrin and is transported to the bone marrow for red cell production.

During inflammation, iron metabolism is changing. In one of these changes, iron is not released from body iron stores (ferritin) because it would enable the development of micro-organisms, which need iron for their growth. Infection and inflammation thus results in hypoferremia. If persistent, it can lead to anaemia. 


\section{Glycosylation of molecules involved in the immune system}

Almost all of the key molecules involved in the innate and adaptive immune response are glycoproteins. In the cellular immune system, specific glycoforms are involved in the folding, quality control and assembly of peptide-loaded major histocompatibility complex (MHC) antigens and the T cell receptor complex [113]. In the humoral immune system, all of the immunoglobulins and most of the complement components are glycosylated [113].

Immunoglobulins are glycoproteins and the major secretory products of the adaptive immune system [6, 79]. They provide long-term defence against foreign antigens [6]. There are five classes identified in humans; $\operatorname{IgG}, \operatorname{IgM}, \operatorname{IgA}, \operatorname{IgE}$ and $\operatorname{IgD}$; they share similar structures and are composed of Ig domains [5]. The immunoglobulins differ in the location and number of $N$-linked glycosylation sites, which are situated on the $\mathrm{Fc}$ and $\mathrm{Fab}$ region and the glycans attached to the immunoglobulins are large, approximately $2 \mathrm{kDa}$ each [6].

\subsection{Decreased galactosylation on immunoglobulin $G$ has impact on its function}

Human serum IgG consists of four subclasses, which differ in their $\gamma$-chain sequences and disulphide bridges. The most abundant serum $\mathrm{Ig}$ is $\mathrm{IgG}_{1}$, which circulates at concentrations of $10-15 \mathrm{mg} / \mathrm{ml}$ [6]. All IgG molecules contain two $N$-linked glycosylation sites, which can be differently glycosylated [6]. The glycan helps to maintain the quaternary structure and the stability of the Fc region $[94,95]$. Aberrant glycosylation of immunoglobulins is linked to disease and pathogenesis, for example, increase in levels of agalactosylated glycoforms of IgG in rheumatoid arthritis [6].

A significant decrease in the level of galactosylation and sialylation in ovarian cancer patients serum has been observed [114]. Increase of agalactosylated IgG oligosaccharides is caused by decreased Gal-T activity in plasma cells [10] or increased production of specific subsets of plasma cells with low expression levels of galactosyltransferases [99]. Different glycoforms may differ in their affinity for ligands [61,89,94,120, 133]. The IgG-G0 glycoform is elevated in rheumatoid arthritis serum [101] and terminal GlcNAc of this glycoform on the Fc region of the $\mathrm{IgG}$ molecule clustered on target cells can be recognized by collagenous lectin mannose-binding protein (MBL) resulting in comple- ment activation [89]. Kaneko et al. [61] have shown that sialylation on $\mathrm{IgG}$ reduces its cytotoxicity to natural killer cells, exhibiting an anti-inflammatory effect. Decreased galactosylation and sialylation on IgG in ovarian cancer patients then may increase the cytotoxicity and complement activation via MBL.

Increase of agalactosylated IgG glycoforms has predominantly been identified with tumour progression and metastasis of gastric and lung cancer [63], as well as in chronic inflammatory diseases such as rheumatoid arthritis, tuberculosis or inflammatory bowel disease $[10,101]$ and vasculitis [56]. IgGs from systemic lupus erythematosus patients with Sjögren's syndrome, also have decreased galactosylation on IgG [18].

Decrease in sialylation on IgG glycans has also been found in rheumatoid arthritis [92]. Therefore, this increase of agalactosylated glycans on IgG of ovarian cancer sera may be indicative of an inflammatory state.

\subsection{Function of the immune response}

The human immune system recognises cancer as an inflammatory process and responds accordingly. It actively produces acute phase proteins, which have also anti-apoptotic properties. In inflammation, it helps to reconstitute the damaged tissue but it protects and promotes cancer cells, considering them as its own. If this hypothesis is correct, anti-inflammatory drugs should have a powerful effect in cancer treatment. Indeed, non-steroidal anti-inflammatory drugs (NSAID) have a positive effect both in prevention [150] and in protection against cancer development and progression [121].

\section{Apoptosis}

Apoptosis is a physiological form of cell death [76]. The term describes a specific morphology during that process and is associated with a distinct set of biochemical and physical changes involving the cytoplasm, nucleus and plasma membrane [76]. Early in apoptosis, cells round up, losing contact with their neighbours and shrink [76]. Under physiological conditions, certain modifications in the plasma membrane occur, which enable the recognition of apoptotic bodies by phagocytic cells [76]. Apoptotic bodies are surrounded by an intact plasma membrane, so, apoptosis usually occurs without leakage of cell content and without inflammation [76]. Apoptosis occurs during embryonic development, tissue remodelling, immune regulation and tumour regression [118]. It is induced by death recep- 
tors, which have been identified as a subgroup of the TNF-receptor superfamily [118].

For cell homeostasis to be maintained, a balance between the increase (differentiation from precursors and proliferation) and decrease (further differentiation and cell death) has to be achieved [76].

\subsection{Apoptosis in cancer}

Apoptosis and the genes that control it have an important effect on the malignant phenotype [83]. Some oncogenic mutations, which disrupt apoptosis, lead to tumour initiation, progression or metastasis [83]. While other oncogenic changes promote apoptosis and over-ride apoptosis during multistage carcinogenesis [83]. The majority of cytotoxic anti-cancer agents induce apoptosis but the possibility of defects in apoptotic programs contribute to treatment failure [83]. The same mutations that suppress apoptosis during tumour development also reduce treatment sensitivity [83]. Therefore, apoptosis provides a link between cancer genetics and cancer therapy [83]. There is intensive research on the mechanisms regulating apoptosis, the results of which will provide new strategies for improving therapeutic outcome [83].

\subsection{Apoptosis and glycosylation}

Glycosylation has an important role in apoptosis. Resistance to apoptosis is a critical feature of cancer cells. Increase of endogenous sialylation, may be one anti-apoptotic mechanism that converts tumour cells to a more malignant phenotype [66]. This supports the finding that sialidase expression is inversely associated with metastatic potential and tumour growth in cancer cells, probably through a regulation mechanism that suppresses cell growth and promotes apoptosis [65].

Galectin-1 is a mammalian lectin that induces cell death in leukemia, lymphoma, breast and prostate cancer. T cells express specific glycoprotein receptors that bear the specific glycans recognized by galectin-1 susceptible to galectin-1 mediated T-cell apoptosis [109]. A characteristic "glycotype" with sialylated core $1 O$ glycans promote galectin-1 resistance [109]. Core $2 N$ acetylglucosaminyltransferase is required for galectin1 susceptibility of T lymphoma and is down-regulated in galectin-1-resistant cells. This indicates that similar $O$-glycan ligands on different polypeptide backbones are common death trigger receptors, recognised by galectin-1 on different types of cancer cells [134]. Loss of galectin-1 susceptibility and synthesis of en- dogenous galectin-1 has been proposed to promote tumor evasion of immune attack [134].

The Golgi enzyme, GlcNAc-TV, is upregulated in cancer and produces $N$-glycans with poly $N$ acetyllactosamine, which is the preferred ligand for galectin-3 [31,102]. GlcNAc-TV glycans have positive effect on tumour growth, metastasis and resistance to apoptosis [31,32].

\section{Conclusion}

Changes in glycosylation are very important in ovarian cancer, providing both potential markers and insight into cancer pathogenesis. Changes in glycosyltransferase levels and/or glycan nucleotide donors, lead to modifications in both $N$ - and $O$ - linked glycans. The most significant $N$-glycosylation changes in ovarian cancer serum glycoproteins are increases in agalactosylated biantennary glycans and SLe ${ }^{\mathrm{x}}$. $N$-glycosylation on CA125 does not contribute to these major changes. An increase of SLe ${ }^{\mathrm{x}}$ has been found on haptoglobin $\beta$ chain, $\alpha 1$-acid glycoprotein and $\alpha 1$-antichymotrypsin. The concentration of these positive acute phase proteins is increased in the acute phase response and this could be affected by the altered glycosylation. A decrease in galactosylation and sialylation on IgG modulates its function. Glycosylation also has an important role in apoptosis, which is deregulated in cancer. Taken together, these data suggest that the progression of ovarian cancer involves pathways which promote cell growth and metastasis, in part bymimicking inflammation processes. Therefore, tumours that survive the host response are these which make changes contributing to its chances for survival.

\section{Acknowledgements}

We acknowledge the Oxford Glycobiology Institute's endowment fund and EUROCarbDB (http:// www.eurocarbdb.org) RIDS Contract No. 011952, for supporting much of the work discussed in this review. We would like to thank Dr. Dereck Chatterton for his contributions to this paper.

\section{Abbreviations}

AGP: $\alpha 1$-acid glycoprotein (also called orosomucoid) 
GlcNAc-TV: $N$-acetylglucosaminyltransferase V

$\mathrm{Hb}$ : haemoglobin

Hp: haptoglobin

IL: interleukin

Le $^{\text {a: }}$ : Lewis a

MBL: mannose-binding lectin

M-CSF: macrophage-colony-stimulating factor

MHC: major histocompatibility complex

NSAID: non-steroidal anti-inflammatory drugs

PSA: polysialic acid

SLe ${ }^{x}$ : sialyl Lewis $\mathrm{x}$

TNF: tumour necrosis factor

TPS: tissue polypeptide specific antigen

\section{References}

[1] Cancer Research UK, [cited 2007 25.4.]; http://info. cancerresearchuk.org/cancerstats/mortality/cancerdeaths/.

[2] Nature and Metabolism of Extracellular Proteins, Molecular Biology of Human Proteins, H.E. Schultze and J.F. Heremans, eds., Amsterdam: Elsevier, 1 (1966), 384-402.

[3] N. Ahmed, K.T. Oliva, G. Barker, P. Hoffmann, S. Reeve, I.A. Smith, M.A. Quinn and G.E. Rice, Proteomic tracking of serum protein isoforms as screening biomarkers of ovarian cancer, Proteomics 5(17) (2005), 4625-4636.

[4] P. Aisen, A. Leibman and J. Zweier, Stoichiometric and site characteristics of the binding of iron to human transferrin, $J$ Biol Chem 253(6) (1978), 1930-1937.

[5] L.M. Amzel and R.J. Poljak, Three-dimensional structure of immunoglobulins, Annu Rev Biochem 48 (1979), 961-997.

[6] J.N. Arnold, M.R. Wormald, R.B. Sim, P.M. Rudd and R.A. Dwek, The Impact of Glycosylation on the Biological Function and Structure of Human Immunoglobulins, Annu Rev Immunol 25 (2007), 21-50.

[7] K.F. Aronsen, G. Ekelund, C.O. Kindmark and C.B. Laurell, Sequential changes of plasma proteins after surgical trauma, Scand J Clin Lab Invest Suppl 124 (1972), 127-136.

[8] M. Aubert, L. Panicot-Dubois, C. Crotte, V. Sbarra, D. Lombardo, M.O. Sadoulet and E. Mas, Peritoneal colonization by human pancreatic cancer cells is inhibited by antisense FUT3 sequence, Int J Cancer 88(4) (2000), 558-565.

[9] M. Aubert, L. Panicot, C. Crotte, P. Gibier, D. Lombardo, M.O. Sadoulet, and E. Mas, Restoration of alpha $(1,2)$ fucosyltransferase activity decreases adhesive and metastatic properties of human pancreatic cancer cells, Cancer Res 60(5) (2000), 1449-1456.

[10] J.S. Axford, N. Sumar, A. Alavi, D.A. Isenberg, A. Young, K.B. Bodman, and I.M. Roitt, Changes in normal glycosylation mechanisms in autoimmune rheumatic disease, $J$ Clin Invest 89(3) (1992), 1021-1031.

[11] Y. Azuma, M. Murata and K. Matsumoto, Alteration of sugar chains on alpha(1)-acid glycoprotein secreted following cytokine stimulation of HuH-7 cells in vitro, Clin Chim Acta 294(1-2) (2000), 93-103.

[12] V.S. Baranov, A.L. Schwartzman, V.N. Gorbunova, V.S. Gaitskhoki, N.B. Rubtsov, N.A. Timchenko and S.A. Neifakh, Chromosomal localization of ceruloplasmin and transferrin genes in laboratory rats, mice and in man by hybridization with specific DNA probes, Chromosoma 96(1) (1987), 6066.
[13] R.C. Bast, Jr. D. Badgwell, Z. Lu, R. Marquez, D. Rosen, J. Liu, K.A. Baggerly, E.N. Atkinson, S. Skates, Z. Zhang, A. Lokshin, U. Menon, I. Jacobs and K. Lu, New tumor markers: CA125 and beyond, Int J Gynecol Cancer 15(3) (2005), 274-281.

[14] R.C. Bast, Jr., M. Feeney, H. Lazarus, L.M. Nadler, R.B. Colvin and R.C. Knapp, Reactivity of a monoclonal antibody with human ovarian carcinoma, J Clin Invest 68(5) (1981), 1331-1337.

[15] K. Beatty, J. Bieth and J. Travis, Kinetics of association of serine proteinases with native and oxidized alpha-1-proteinase inhibitor and alpha-1-antichymotrypsin, J Biol Chem 255(9) (1980), 3931-3934.

[16] S. Bengtsson, M. Krogh, C.A. Szigyarto, M. Uhlen, K. Schedvins, C. Silfversward, S. Linder, G. Auer, A. Alaiya and P. James, Large-scale proteomics analysis of human ovarian cancer for biomarkers, J Proteome Res 6(4) (2007), 14401450

[17] J.A. Black, G.F. Chan, C.L. Hew and G.H. Dixon, Gene action in the human haptoglobins. 3. Isolation of the alphachains as single gene products. Isolation, molecular weight, and amino acid composition of alpha and beta chains, Can J Biochem 48(1) (1970), 123-132.

[18] A. Bond, A. Alavi, J.S. Axford, B.E. Bourke, F.E. Bruckner, M.A. Kerr, J.D. Maxwell, K.J. Tweed, M.J. Weldon, P. Youinou and F.C. Hay, A detailed lectin analysis of IgG glycosylation, demonstrating disease specific changes in terminal galactose and $\mathrm{N}$-acetylglucosamine, J Autoimmun 10(1) (1997), 77-85.

[19] B.H. Bowman, F.M. Yang and G.S. Adrian, Transferrin: evolution and genetic regulation of expression, Adv Genet $\mathbf{2 5}$ (1988), 1-38.

[20] B.H. Bowman, Haptoglobin, in: Hepatic Plasma Proteins, B.H. Bowman, Ed., Academic Press: San Diego, 1993, pp. $159-167$.

[21] C.F. Brewer and L. Bhattacharyya, Specificity of concanavalin A binding to asparagine-linked glycopeptides. A nuclear magnetic relaxation dispersion study, J Biol Chem 261(16) (1986), 7306-7310.

[22] E.C. Brinkman-Van der Linden, P.F. de Haan, E.C. Havenaar and W. Van Dijk, Inflammation-induced expression of sialyl LewisX is not restricted to alpha1-acid glycoprotein but also occurs to a lesser extent on alpha1-antichymotrypsin and haptoglobin, Glycoconj J 15(2) (1998), 177-182.

[23] S.A. Brooks, M.W. Dwek and U. Schumacher, Functional \& Molecular Glycobiology P. Dines, Oxford: BIOS Scientific Publishers Limited, 2002.

[24] S.L. Byrne, R. Leverence, J.S. Klein, A.M. Giannetti, V.C. Smith, R.T. MacGillivray, I.A. Kaltashov and A.B. Mason, Effect of glycosylation on the function of a soluble, recombinant form of the transferrin receptor, Biochemistry $\mathbf{4 5}(21)$ (2006), 6663-6673.

[25] G. Camussi, C. Tetta, F. Bussolino and C. Baglioni, Synthesis and release of platelet-activating factor is inhibited by plasma alpha 1-proteinase inhibitor or alpha 1-antichymotrypsin and is stimulated by proteinases, J Exp Med 168(4) (1988), 12931306.

[26] P.J. Coombs, M.E. Taylor and K. Drickamer, Two categories of mammalian galactose-binding receptors distinguished by glycan array profiling, Glycobiology 16(8) (2006), 1C-7C.

[27] M. Costello, B.A. Fiedel and H. Gewurz, Inhibition of platelet aggregation by native and desialised alpha-1 acid glycoprotein, Nature 281(5733) (1979), 677-678. 
[28] M.A. Daemen, V.H. Heemskerk, C. van't Veer, G. Denecker, T.G. Wolfs, P. Vandenabeele and W.A. Buurman, Functional protection by acute phase proteins alpha(1)-acid glycoprotein and alpha(1)-antitrypsin against ischemia/reperfusion injury by preventing apoptosis and inflammation, Circulation 102(12) (2000), 1420-1426.

[29] T.W. De Graaf, M.E. Van der Stelt, M.G. Anbergen and W. van Dijk, Inflammation-induced expression of sialyl Lewis X-containing glycan structures on alpha 1-acid glycoprotein (orosomucoid) in human sera, J Exp Med 177(3) (1993), 657-666.

[30] G. de Jong, J.P. van Dijk and H.G. van Eijk, The biology of transferrin, Clin Chim Acta 190(1-2) (1990), 1-46.

[31] J.W. Dennis, J. Pawling, P. Cheung, E. Partridge and M. Demetriou, UDP-N-acetylglucosamine:alpha-6-Dmannoside beta1, $6 \mathrm{~N}$-acetylglucosaminyltransferase $\mathrm{V}$ (Mgat5) deficient mice, Biochim Biophys Acta 1573(3) (2002), 414-422.

[32] J.W. Dennis, S. Laferte, C. Waghorne, M.L. Breitman and R.S. Kerbel, Beta 1-6 branching of Asn-linked oligosaccharides is directly associated with metastasis, Science 236(4801) (1987), 582-585.

[33] D.H. Dube and C.R. Bertozzi, Glycans in cancer and inflammation-potential for therapeutics and diagnostics, Nat Rev Drug Discov 4(6) (2005), 477-488.

[34] M.J. Duffy, J.M. Bonfrer, J. Kulpa, G.J. Rustin, G. Soletormos, G.C. Torre, M.K. Tuxen and M. Zwirner, CA125 in ovarian cancer: European Group on Tumor Markers guidelines for clinical use, Int J Gynecol Cancer 15(5) (2005), 679-691.

[35] T. Emoto, K. Nakamura, Y. Nagasaka, F. Numa, Y. Suminami and H. Kato, Alpha 1-antichymotrypsin inhibits chymotrypsin-induced apoptosis in rat hepatoma cells, Apoptosis 3(3) (1998), 155-160.

[36] D. Formanowicz, A. Sackmann, P. Formanowicz and J. Blazewicz, Petri net based model of the body iron homeostasis, J Biomed Inform, 2006.

[37] T. Fournier, N.N. Medjoubi and D. Porquet, Alpha-1-acid glycoprotein, Biochim Biophys Acta 1482(1-2) (2000), 157171.

[38] T. Fujimura, Y. Shinohara, B. Tissot, P.C. Pang, M. Kurogochi, S. Saito, Y. Arai, M. Sadilek, K. Murayama, A. Dell, S. Nishimura and S.I. Hakomori, Glycosylation status of haptoglobin in sera of patients with prostate cancer vs. benign prostate disease or normal subjects, Int J Cancer 122(1) (2008), 39-49.

[39] M. Fukuda, E. Spooncer, J.E. Oates, A. Dell and J.C. Klock, Structure of sialylated fucosyl lactosaminoglycan isolated from human granulocytes, J Biol Chem 259(17) (1984), 10925-10935.

[40] C. Gabay, Interleukin-6 and chronic inflammation, Arthritis Res Ther 8(2) (2006), S3.

[41] C. Gabay and I. Kushner, Acute-phase proteins and other systemic responses to inflammation, $N$ Engl J Med 340(6) (1999), 448-454.

[42] K.C. Gatter, G. Brown, I.S. Trowbridge, R.E. Woolston and D.Y. Mason, Transferrin receptors in human tissues: their distribution and possible clinical relevance, J Clin Pathol 36(5) (1983), 539-545.

[43] M.K. Georgieff, C.D. Petry, M.M. Mills, H. McKay and J.D. Wobken, Increased N-glycosylation and reduced transferrinbinding capacity of transferrin receptor isolated from placentae of diabetic women, Placenta 18(7) (1997), 563-568.
[44] C. Gercel-Taylor, L.B. Bazzett and D.D. Taylor, Presence of aberrant tumor-reactive immunoglobulins in the circulation of patients with ovarian cancer, Gynecol Oncol 81(1) (2001), 71-76.

[45] E.R. Giblett, The haptoglobin system., Series Haematologica 1 (1968), 3-20.

[46] M.T. Goodarzi and G.A. Turner, Reproducible and sensitive determination of charged oligosaccharides from haptoglobin by PNGase F digestion and HPAEC/PAD analysis: glycan composition varies with disease, Glycoconj J 15(5) (1998), 469-475.

[47] O. Gornik, L. Royle, D.J. Harvey, C.M. Radcliffe, R. Saldova, R.A. Dwek, P. Rudd and G. Lauc, Changes of serum glycans during sepsis and acute pancreatitis, Glycobiology 17(12) (2007), 1321-1332.

[48] S. Hakomori and Y. Zhang, Glycosphingolipid antigens and cancer therapy, Chem Biol 4(2) (1997), 97-104.

[49] S. Hakomori and A. Kobata, in: The Antigens, M. Sela, Ed., Academic Press: New York, 1974, pp. 79-140.

[50] J. Hamori, P. Arkosy, A. Lenkey and P. Sapy, The role of different tumor markers in the early diagnosis and prognosis of pancreatic carcinoma and chronic pancreatitis, Acta Chir Hung 36(1-4) (1997), 125-127.

[51] D.C. Harris and P. Aisen, Iron Carriers and Iron Proteins, New York: VCH Publishers, 1989.

[52] Z. He, L.P. Aristoteli, L. Kritharides and B. Garner, HPLC analysis of discrete haptoglobin isoform N-linked oligosaccharides following 2D-PAGE isolation, Biochem Biophys Res Commun 343(2) (2006), 496-503.

[53] L.F.t. Hoagland, M.J. Campa, E.B. Gottlin, J.E. Herndon, 2nd and E.F. Patz, Jr., Haptoglobin and posttranslational glycanmodified derivatives as serum biomarkers for the diagnosis of nonsmall cell lung cancer, Cancer 110(10) (2007), 22602268.

[54] T. Hochepied, F.G. Berger, H. Baumann and C. Libert, Alpha(1)-acid glycoprotein: an acute phase protein with inflammatory and immunomodulating properties, Cytokine Growth Factor Rev 14(1) (2003), 25-34.

[55] P. Hoefkens, M.I. Huijskes-Heins, C.M. de Jeu-Jaspars, W.L. van Noort, and H.G. van Eijk, Influence of transferrin glycans on receptor binding and iron-donation, Glycoconj $J$ 14(2) (1997), 289-295.

[56] M. Holland, K. Takada, T. Okumoto, N. Takahashi, K. Kato, D. Adu, A. Ben-Smith, L. Harper, C.O. Savage and R. Jefferis, Hypogalactosylation of serum IgG in patients with ANCA-associated systemic vasculitis, Clin Exp Immunol 129(1) (2002), 183-190.

[57] D. Hudig, T. Haverty, C. Fulcher, D. Redelman and J. Mendelsohn, Inhibition of human natural cytotoxicity by macromolecular antiproteases, J Immunol 126(4) (1981), 1569-1574.

[58] M. Huleihel, E. Maymon, B. Piura, I. Prinsloo, D. Benharroch, I. Yanai-Inbar and M. Glezerman, Distinct patterns of expression of interleukin-1 alpha and beta by normal and cancerous human ovarian tissues, Eur Cytokine Netw 8(2)(1997), 179-187.

[59] Y. Ishibashi, Y. Inouye, T. Okano and A. Taniguchi, Regulation of sialyl-Lewis $\mathrm{x}$ epitope expression by TNF-alpha and EGF in an airway carcinoma cell line, Glycoconj $J$ 22(1-2) (2005), 53-62.

[60] Z.H. Israili and P.G. Dayton, Human alpha-1-glycoprotein and its interactions with drugs, Drug Metab Rev 33(2) (2001), 161-235. 
[61] Y. Kaneko, F. Nimmerjahn and J.V. Ravetch, Antiinflammatory activity of immunoglobulin $\mathrm{G}$ resulting from Fc sialylation, Science 313(5787) (2006), 670-673.

[62] D. Kanikowska, R. Madry, J. Drozdz-Gorska, M. Sobieska, J. Markowska, and K. Wiktorowicz, [Microheterogeneity of two acute phase proteins in patients with ovarian carcinoma], Ginekol Pol 72(1) (2001), 17-21.

[63] Y. Kanoh, T. Mashiko, M. Danbara, Y. Takayama, S. Ohtani, T. Imasaki, T. Abe and T. Akahoshi, Analysis of the oligosaccharide chain of human serum immunoglobulin $g$ in patients with localized or metastatic cancer, Oncology 66(5) (2004), 365-370.

[64] A.I. Karseladze, I.E. Rytin and V.B. Matveev, [Study of alpha1-antichymotrypsin (ACT) in prostatic carcinoma], Arkh Patol 67(1) (2005), 30-33.

[65] T. Kato, Y. Wang, K. Yamaguchi, C.M. Milner, R. Shineha, S. Satomi and T. Miyagi, Overexpression of lysosomal-type sialidase leads to suppression of metastasis associated with reversion of malignant phenotype in murine B16 melanoma cells, Int J Cancer 92(6) (2001), 797-804.

[66] O.T. Keppler, M.E. Peter, S. Hinderlich, G. Moldenhauer, P. Stehling, I. Schmitz, R. Schwartz-Albiez, W. Reutter and M. Pawlita, Differential sialylation of cell surface glycoconjugates in a human B lymphoma cell line regulates susceptibility for CD95 (APO-1/Fas)-mediated apoptosis and for infection by a lymphotropic virus, Glycobiology 9(6) (1999), 557-569.

[67] L. Kilpatrick, J.L. Johnson, E.B. Nickbarg, Z.M. Wang, T.F. Clifford, M. Banach, B.S. Cooperman, S.D. Douglas and H. Rubin, Inhibition of human neutrophil superoxide generation by alpha 1-antichymotrypsin, J Immunol 146(7) (1991), 2388-2393.

[68] Y.J. Kim and A. Varki, Perspectives on the significance of altered glycosylation of glycoproteins in cancer, Glycoconj $J$ 14(5) (1997), 569-576.

[69] K.R. Kozak, F. Su, J.P. Whitelegge, K. Faull, S. Reddy and R. Farias-Eisner, Characterization of serum biomarkers for detection of early stage ovarian cancer, Proteomics 5(17) (2005), 4589-4596.

[70] J.M. Kremer, J. Wilting and L.H. Janssen, Drug binding to human alpha-1-acid glycoprotein in health and disease, Pharmacol Rev 40(1) (1988), 1-47.

[71] N. Kui Wong, R.L. Easton, M. Panico, M. Sutton-Smith, J.C. Morrison, F.A. Lattanzio, H.R. Morris, G.F. Clark, A. Dell and M.S. Patankar, Characterization of the oligosaccharides associated with the human ovarian tumor marker CA125, $J$ Biol Chem 278(31) (2003), 28619-28634.

[72] A. Kurosky, D.R. Barnett, T.H. Lee, B. Touchstone, R.E. Hay, M.S. Arnott, B.H. Bowman and W.M. Fitch, Covalent structure of human haptoglobin: a serine protease homolog, Proc Natl Acad Sci USA 77(6) (1980), 3388-3392.

[73] A. Laine, E. Hachulla, G. Strecker, J.C. Michalski and J.M. Wieruszeski, Structure determination of the glycans of human-serum alpha 1-antichymotrypsin using 1H-NMR spectroscopy and deglycosylation by N-glycanase, Eur $J$ Biochem 197(1) (1991), 209-215.

[74] A. Laine and A. Hayem, Purification and characterization of alpha 1-antichymotrypsin from human pleural fluid and human serum, Biochim Biophys Acta 668(3) (1981), 429438.

[75] M.R. Langlois and J.R. Delanghe, Biological and clinical significance of haptoglobin polymorphism in humans, Clin Chem 42(10) (1996), 1589-1600.
[76] A. Lawen, Apoptosis-an introduction, Bioessays 25(9) (2003), 888-896.

[77] V. Lesnikov, M. Lesnikova and H.J. Deeg, Pro-apoptotic and anti-apoptotic effects of transferrin and transferrin-derived glycans on hematopoietic cells and lymphocytes, Exp Hematol 29(4) (2001), 477-489.

[78] A. Liede, B.Y. Karlan, R.L. Baldwin, L.D. Platt, G. Kuperstein and S.A. Narod, Cancer incidence in a population of Jewish women at risk of ovarian cancer, J Clin Oncol 20(6) (2002), 1570-1577.

[79] G.W. Litman, M.K. Anderson and J.P. Rast, Evolution of antigen binding receptors, Annu Rev Immunol 17 (1999), 109-147.

[80] J. Llorca, M.J. Lopez-Diaz, C. Gonzalez-Juanatey, W.E. Ollier, J. Martin and M.A. Gonzalez-Gay, Persistent Chronic Inflammation Contributes to the Development of Cancer in Patients with Rheumatoid Arthritis from a Defined Population of Northwestern Spain, Semin Arthritis Rheum, 2007.

[81] L. Logdberg and L. Wester, Immunocalins: a lipocalin subfamily that modulates immune and inflammatory responses, Biochim Biophys Acta 1482(1-2) (2000), 284-297.

[82] C.N. Lok and T.T. Loh, Regulation of transferrin function and expression: review and update, Biol Signals Recept 7(3) (1998), 157-178

[83] S.W. Lowe and A.W. Lin, Apoptosis in cancer, Carcinogenesis 21(3) (2000), 485-495.

[84] A. Mackiewicz and K. Mackiewicz, Glycoforms of serum alpha 1-acid glycoprotein as markers of inflammation and cancer, Glycoconj J 12(3) (1995), 241-247.

[85] A. Mackiewicz, M. Laciak, A. Gorny and H. Baumann, Leukemia inhibitory factor, interferon gamma and dexamethasone regulate $\mathrm{N}$-glycosylation of alpha 1-protease inhibitor in human hepatoma cells, Eur J Cell Biol 60(2) (1993), 331-336.

[86] A. Mackiewicz, M.K. Ganapathi, D. Schultz and I. Kushner, Monokines regulate glycosylation of acute-phase proteins, $J$ Exp Med 166(1) (1987), 253-258.

[87] A. Mackiewicz and I. Kushner, Interferon beta 2/B-cell stimulating factor $2 /$ interleukin 6 affects glycosylation of acute phase proteins in human hepatoma cell lines, Scand J Immunol 29(3) (1989), 265-271.

[88] J.L. Magnani, The discovery, biology and drug development of sialyl Lea and sialyl Lex, Arch Biochem Biophys 426(2) (2004), 122-131.

[89] R. Malhotra, M.R. Wormald, P.M. Rudd, P.B. Fischer, R.A. Dwek and R.B. Sim, Glycosylation changes of IgG associated with rheumatoid arthritis can activate complement via the mannose-binding protein, Nat Med 1(3) (1995), 237-243.

[90] A.B. Mason, Q.Y. He, P.J. Halbrooks, S.J. Everse, D.R. Gumerov, I.A. Kaltashov, V.C. Smith, J. Hewitt and R.T. MacGillivray, Differential effect of a his tag at the N-and Ctermini: functional studies with recombinant human serum transferrin, Biochemistry 41(30) (2002), 9448-9454.

[91] A.B. Mason, M.K. Miller, W.D. Funk, D.K. Banfield, K.J. Savage, R.W. Oliver, B.N. Green, R.T. MacGillivray and R.C. Woodworth, Expression of glycosylated and nonglycosylated human transferrin in mammalian cells. Characterization of the recombinant proteins with comparison to three commercially available transferrins, Biochemistry 32(20) (1993), 5472-5479.

[92] A. Matsumoto, K. Shikata, F. Takeuchi, N. Kojima and T. Mizuochi, Autoantibody activity of IgG rheumatoid factor increases with decreasing levels of galactosylation and sialylation, J Biochem (Tokyo) 128(4) (2000), 621-628. 
[93] R.P. McEver, Selectin-carbohydrate interactions during inflammation and metastasis, Glycoconj J 14(5) (1997), 585591.

[94] Y. Mimura, S. Church, R. Ghirlando, P.R. Ashton, S. Dong, M. Goodall, J. Lund and R. Jefferis, The influence of glycosylation on the thermal stability and effector function expression of human IgG1-Fc: properties of a series of truncated glycoforms, Mol Immunol 37(12-13) (2000), 697-706.

[95] Y. Mimura, P. Sondermann, R. Ghirlando, J. Lund, S.P. Young, M. Goodall and R. Jefferis, Role of oligosaccharide residues of IgG1-Fc in Fc gamma RIIb binding, $J$ Biol Chem 276(49) (2001), 45539-45547.

[96] R.B. Ness and C. Cottreau, Possible role of ovarian epithelial inflammation in ovarian cancer, J Natl Cancer Inst 91(17) (1999), 1459-1467.

[97] M.B. Nilsson, R.R. Langley and I.J. Fidler, Interleukin-6, secreted by human ovarian carcinoma cells, is a potent proangiogenic cytokine, Cancer Res 65(23) (2005), 10794-10800.

[98] N. Okuyama, Y. Ide, M. Nakano, T. Nakagawa, K. Yamanaka, K. Moriwaki, K. Murata, H. Ohigashi, S. Yokoyama, H. Eguchi, O. Ishikawa, T. Ito, M. Kato, A. Kasahara, S. Kawano, J. Gu, N. Taniguchi and E. Miyoshi, Fucosylated haptoglobin is a novel marker for pancreatic cancer: a detailed analysis of the oligosaccharide structure and a possible mechanism for fucosylation, Int J Cancer 118(11) (2006), 2803-2808.

[99] L.A. Omtvedt, L. Royle, G. Husby, K. Sletten, C.M. Radcliffe, D.J. Harvey, R.A. Dwek and P.M. Rudd, Glycan analysis of monoclonal antibodies secreted in deposition disorders indicates that subsets of plasma cells differentially process IgG glycans, Arthritis Rheum 54(11) (2006), 3433-3440.

[100] G. Orberger, H. Fuchs, R. Geyer, R. Gessner, E. Kottgen and R. Tauber, Structural and functional stability of the mature transferrin receptor from human placenta, Arch Biochem Biophys 386(1) (2001), 79-88.

[101] R.B. Parekh, R.A. Dwek, B.J. Sutton, D.L. Fernandes, A. Leung, D. Stanworth, T.W. Rademacher, T. Mizuochi, T. Taniguchi, K. Matsuta et al., Association of rheumatoid arthritis and primary osteoarthritis with changes in the glycosylation pattern of total serum IgG, Nature 316(6027) (1985), 452-457.

[102] E.A. Partridge, C. Le Roy, G.M. Di Guglielmo, J. Pawling, P. Cheung, M. Granovsky, I.R. Nabi, J.L. Wrana and J.W. Dennis, Regulation of cytokine receptors by Golgi N-glycan processing and endocytosis, Science 306(5693) (2004), 120 124.

[103] J. Petaja, S. Pitkanen, K. Vettenranta, A. Fasth and M. Heikinheimo, Serum tumor marker CA 125 is an early and sensitive indicator of veno-occlusive disease in children undergoing bone marrow transplantation, Clin Cancer Res 6(2) (2000), 531-535.

[104] A.J. Petrescu, A.L. Milac, S.M. Petrescu, R.A. Dwek and M.R. Wormald, Statistical analysis of the protein environment of N-glycosylation sites: implications for occupancy, structure and folding, Glycobiology 14(2) (2004), 103-114.

[105] M.S. Piver, T.R. Baker, M. Piedmonte and A.M. Sandecki, Epidemiology and etiology of ovarian cancer, Semin Oncol. 18(3) (1991), 177-185.

[106] O. Pos, R.A. Oostendorp, M.E. van der Stelt, R.J. Scheper and W. Van Dijk, Con A-nonreactive human alpha 1-acid glycoprotein (AGP) is more effective in modulation of lymphocyte proliferation than Con A-reactive AGP serum variants, Inflammation 14(2) (1990), 133-141.
[107] H. Rauvala, Gangliosides of human kidney, J Biol Chem 251(23) (1976), 7517-7520.

[108] R.F. Ritchie, G.E. Palomaki, L.M. Neveux, O. Navolotskaia, T.B. Ledue, and W.Y. Craig, Reference distributions for the negative acute-phase serum proteins, albumin, transferrin and transthyretin: a practical, simple and clinically relevant approach in a large cohort, J Clin Lab Anal 13(6) (1999), 273-279.

[109] A.A. Roberts, M. Amano, C. Felten, M. Galvan, G. Sulur, L. Pinter-Brown, U. Dobbeling, G. Burg, J. Said and L.G. Baum, Galectin-1-mediated apoptosis in mycosis fungoides: the roles of CD7 and cell surface glycosylation, Mod Pathol 16(6) (2003), 543-551.

[110] T.M. Robinson-Smith, I. Isaacsohn, C.A. Mercer, M. Zhou, N. Van Rooijen, N. Husseinzadeh, M.M. McFarlandMancini and A.F. Drew, Macrophages mediate inflammationenhanced metastasis of ovarian tumors in mice, Cancer Res 67(12) (2007), 5708-5716.

[111] C. Rodriguez, A.V. Patel, E.E. Calle, E.J. Jacob and M.J. Thun, Estrogen replacement therapy and ovarian cancer mortality in a large prospective study of US women, Jama 285(11) (2001), 1460-1465.

[112] H. Rubin, Z.M. Wang, E.B. Nickbarg, S. McLarney, N. Naidoo, O.L. Schoenberger, J.L. Johnson and B.S. Cooperman, Cloning, expression, purification and biological activity of recombinant native and variant human alpha 1antichymotrypsins, J Biol Chem 265(2) (1990), 1199-1207.

[113] P.M. Rudd, T. Elliott, P. Cresswell, I.A. Wilson and R.A. Dwek, Glycosylation and the immune system, Science 291(5512) (2001), 2370-2376.

[114] R. Saldova, L. Royle, C.M. Radcliffe, U.M. Abd Hamid, R. Evans, J.N. Arnold, R.E. Banks, R. Hutson, D.J. Harvey, R. Antrobus, S.M. Petrescu, R.A. Dwek and P.M. Rudd, Ovarian Cancer is Associated with Changes in Glycosylation in Both Acute-Phase Proteins and IgG, Glycobiology 17(12) (2007), 1344-1356.

[115] Y. Satomi, Y. Shimonishi, T. Hase and T. Takao, Site-specific carbohydrate profiling of human transferrin by nano-flow liquid chromatography/electrospray ionization mass spectrometry, Rapid Commun Mass Spectrom 18(24) (2004), 29832988.

[116] Y. Satomi, Y. Shimonishi and T. Takao, N-glycosylation at Asn(491) in the Asn-Xaa-Cys motif of human transferrin, FEBS Lett 576(1-2) (2004), 51-56.

[117] K. Schmid, R.B. Nimerg, A. Kimura, H. Yamaguchi and J.P. Binette, The carbohydrate units of human plasma alpha1-acid glycoprotein, Biochim Biophys Acta 492(2) (1977), 291-302.

[118] K. Schulze-Osthoff, D. Ferrari, M. Los, S. Wesselborg and M.E. Peter, Apoptosis signaling by death receptors, Eur J Biochem 254(3) (1998), 439-459.

[119] S. Sell, Cancer-associated carbohydrates identified by monoclonal antibodies, Hum Pathol 21(10) (1990), 1003-1019.

[120] R.L. Shields, J. Lai, R. Keck, L.Y. O'Connell, K. Hong, Y.G. Meng, S.H. Weikert and L.G. Presta, Lack of fucose on human IgG1 N-linked oligosaccharide improves binding to human Fcgamma RIII and antibody-dependent cellular toxicity, J Biol Chem 277(30) (2002), 26733-26740.

[121] S.S. Smyth and C. Patterson, Tiny dancers: the integringrowth factor nexus in angiogenic signaling, $J$ Cell Biol 158(1) (2002), 17-21.

[122] R.J. Stockert, The asialoglycoprotein receptor: relationships between structure, function and expression, Physiol Rev 75(3) (1995), 591-609. 
[123] G. Tabares, C.M. Radcliffe, S. Barrabes, M. Ramirez, R.N Aleixandre, W. Hoesel, R.A. Dwek, P.M. Rudd, R. Peracaula and R. de Llorens, Different glycan structures in prostatespecific antigen from prostate cancer sera in relation to seminal plasma PSA, Glycobiology 16(2) (2006), 132-145.

[124] D.G. Tang and K.V. Honn, Adhesion molecules and tumor metastasis: an update, Invasion Metastasis 14(1-6) (1994), 109-122.

[125] J. Taylor-Papadimitriou and A.A. Epenetos, Exploiting altered glycosylation patterns in cancer: progress and challenges in diagnosis and therapy, Trends Biotechnol 12(6) (1994), 227-233.

[126] S. Thompson, E. Dargan and G.A. Turner, Increased fucosylation and other carbohydrate changes in haptoglobin in ovarian cancer, Cancer Lett 66(1) (1992), 43-48.

[127] S. Thompson and G.A. Turner, Elevated levels of abnormallyfucosylated haptoglobins in cancer sera, Br J Cancer 56(5) (1987), 605-610.

[128] J. Tosner, J. Krejsek and B. Louda, Serum prealbumin, transferrin and alpha-1-acid glycoprotein in patients with gynecological carcinomas, Neoplasma 35(4) (1988), 403-411.

[129] J. Travis, J. Bowen and R. Baugh, Human alpha-1antichymotrypsin: interaction with chymotrypsin-like proteinases, Biochemistry 17(26) (1978), 5651-5656.

[130] J. Travis and G.S. Salvesen, Human plasma proteinase inhibitors, Апnи Rev Biochem 52 (1983), 655-709.

[131] G.A. Turner, M.T. Goodarzi and S. Thompson, Glycosylation of alpha-1-proteinase inhibitor and haptoglobin in ovarian cancer: evidence for two different mechanisms, Glycoconj $J$ 12(3) (1995), 211-218.

[132] M. Ugorski and A. Laskowska, Sialyl Lewis(a): a tumorassociated carbohydrate antigen involved in adhesion and metastatic potential of cancer cells, Acta Biochim Pol 49(2) (2002), 303-311.

[133] P. Umana, J. Jean-Mairet, R. Moudry, H. Amstutz and J.E. Bailey, Engineered glycoforms of an antineuroblastoma IgG1 with optimized antibody-dependent cellular cytotoxic activity, Nat Biotechnol 17(2) (1999), 176-180.

[134] H.F. Valenzuela, K.E. Pace, P.V. Cabrera, R. White, K. Porvari, H. Kaija, P. Vihko and L.G. Baum, O-glycosylation regulates LNCaP prostate cancer cell susceptibility to apoptosis induced by galectin-1, Cancer Res 67(13) (2007), 61556162.

[135] W. van Dijk, E.C. Havenaar and E.C. Brinkman-van der Linden, Alpha 1-acid glycoprotein (orosomucoid): pathophysiological changes in glycosylation in relation to its function, Glycoconj J 12(3) (1995), 227-233.

[136] W. van Dijk, G.A. Turner and A. Mackiewicz, Changes in glycosylation of acute phase proteins in health and disease: occurence, regulation and function, Glycosyl Dis 1 (1994), $5-14$.

[137] W. Van Dijk and A. Mackiewicz, Interleukin-6-type cytokine-induced changes in acute phase protein glycosylation, Ann NY Acad Sci 762 (1995), 319-330.
[138] H. Van Vlierberghe, M. Langlois and J. Delanghe, Haptoglobin polymorphisms and iron homeostasis in health and in disease, Clin Chim Acta 345(1-2) (2004), 35-42.

[139] J. Wally and S.K. Buchanan, A structural comparison of human serum transferrin and human lactoferrin, Biometals, 2007.

[140] C. Wandersman and P. Delepelaire, Bacterial iron sources: from siderophores to hemophores, Аnnu Rev Microbiol $\mathbf{5 8}$ (2004), 611-647.

[141] P.H. Wang, W.L. Lee, C.M. Juang, Y.H. Yang, W.H. Lo, C.R. Lai, S.L. Hsieh and C.C. Yuan, Altered mRNA expressions of sialyltransferases in ovarian cancers, Gynecol Oncol 99(3) (2005), 631-639.

[142] W.T. Wang, T. Lundgren, F. Lindh, B. Nilsson, G. Gronberg, J.P. Brown, H. Mentzer-Dibert and D. Zopf, Isolation of two novel sialyl-Lewis $\mathrm{X}$-active oligosaccharides by high-performance liquid affinity chromatography using monoclonal antibody Onc-M26, Arch Biochem Biophys 292(2) (1992), 433-441.

[143] M.R. Wormald, A.J. Petrescu, Y.L. Pao, A. Glithero, T. Elliott and R.A. Dwek, Conformational studies of oligosaccharides and glycopeptides: complementarity of NMR, X-ray crystallography and molecular modelling, Chem Rev 102(2) (2002), 371-386.

[144] K. Yamashita, N. Koide, T. Endo, Y. Iwaki and A. Kobata, Altered glycosylation of serum transferrin of patients with hepatocellular carcinoma, J Biol Chem 264(5) (1989), 24152423.

[145] S. Yazawa, R. Madiyalakan, M.S. Piver and K.L. Matta, Elevated activities of blood group Le gene dependent alpha(13)-L-fucosyltransferase in human saliva of Lewis negative patients with epithelial ovarian cancer, Cancer Lett 32(2) (1986), 165-169.

[146] B. Ye, S. Skates, S.C. Mok, N.K. Horick, H.F. Rosenberg, A. Vitonis, D. Edwards, P. Sluss, W.K. Han, R.S. Berkowitz and D.W. Cramer, Proteomic-based discovery and characterization of glycosylated eosinophil-derived neurotoxin and $\mathrm{COOH}$-terminal osteopontin fragments for ovarian cancer in urine, Clin Cancer Res 12(2) (2006), 432-441.

[147] H. Yoshima, A. Matsumoto, T. Mizuochi, T. Kawasaki and A. Kobata, Comparative study of the carbohydrate moieties of rat and human plasma alpha 1-acid glycoproteins, $J$ Biol Chem 256(16) (1981), 8476-8484.

[148] G. Zanotti, V. Calderone, M. Beda, G. Malpeli, C. Folli and R. Berni, Structure of chicken plasma retinol-binding protein, Biochim Biophys Acta 1550(1) (2001), 64-69.

[149] S.Zhang, H.S. Zhang, V.E. Reuter, S.F. Slovin, H.I. Scher and P.O. Livingston, Expression of potential target antigens for immunotherapy on primary and metastatic prostate cancers, Clin Cancer Res 4(2) (1998), 295-302.

[150] Y.Zhang, P.F. Coogan, J.R. Palmer, B.L. Strom and L. Rosenberg, Use of nonsteroidal antiinflammatory drugs and risk of breast cancer: the Case-Control Surveillance Study revisited, Am J Epidemiol 162(2) (2005), 165-170. 


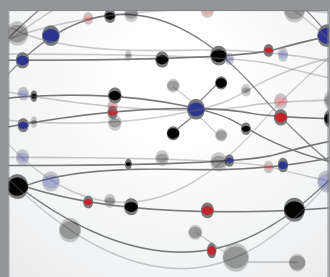

The Scientific World Journal
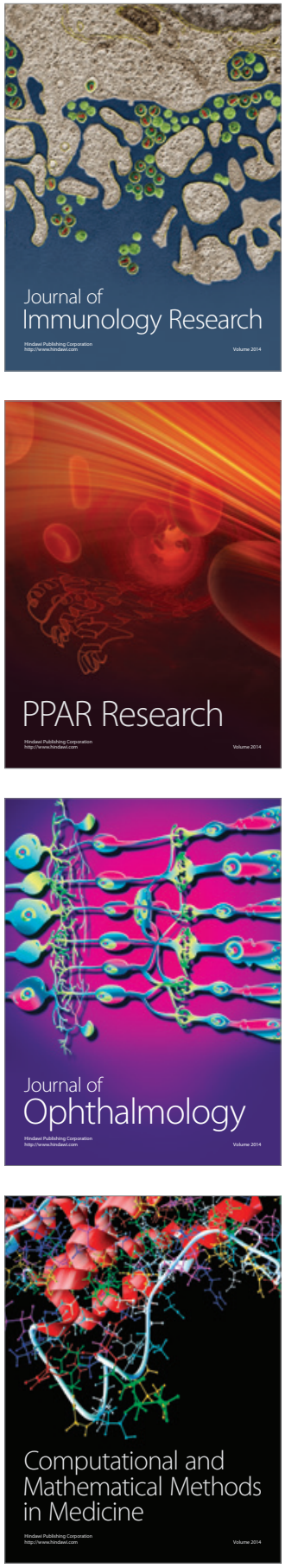

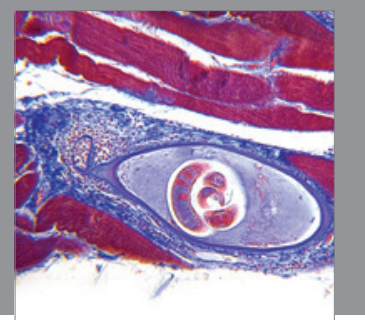

Gastroenterology

Research and Practice
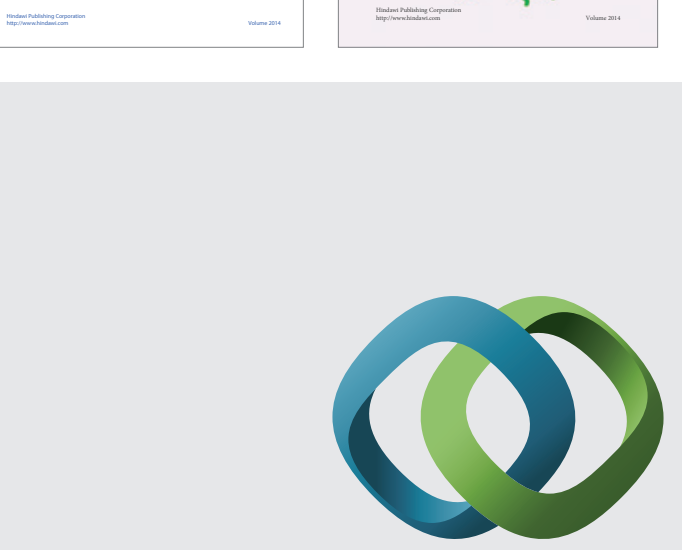

\section{Hindawi}

Submit your manuscripts at

http://www.hindawi.com
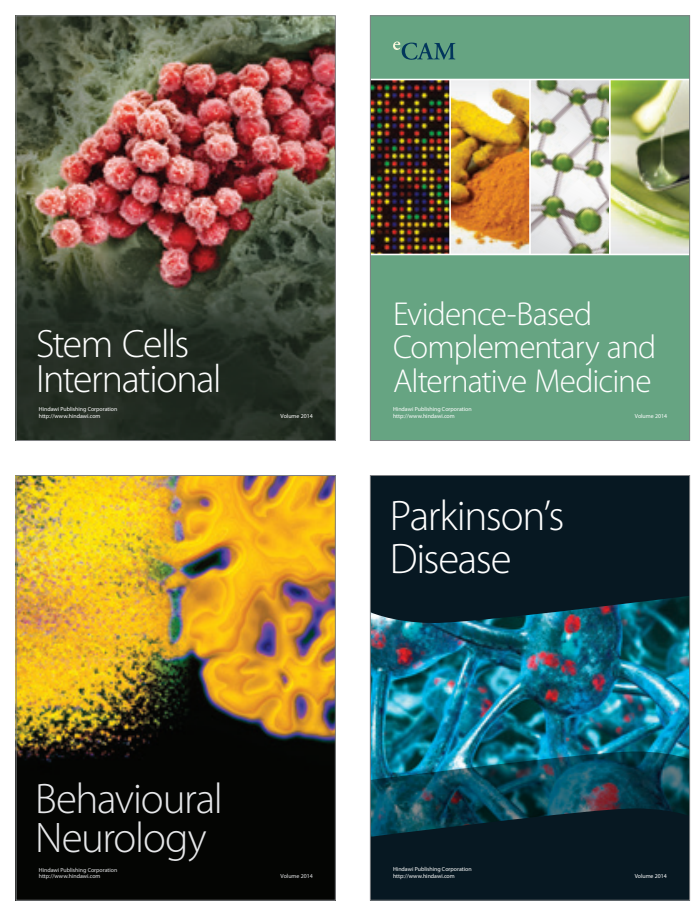

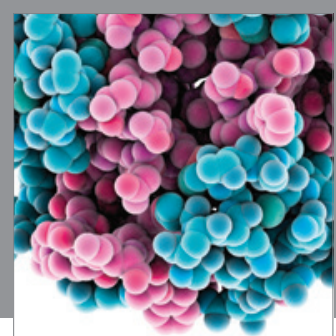

Journal of
Diabetes Research

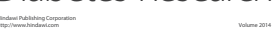

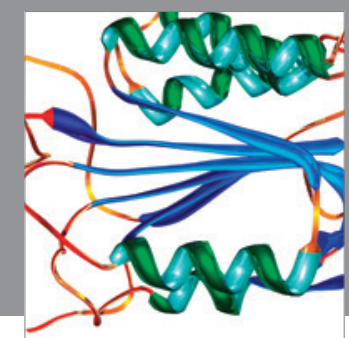

Disease Markers
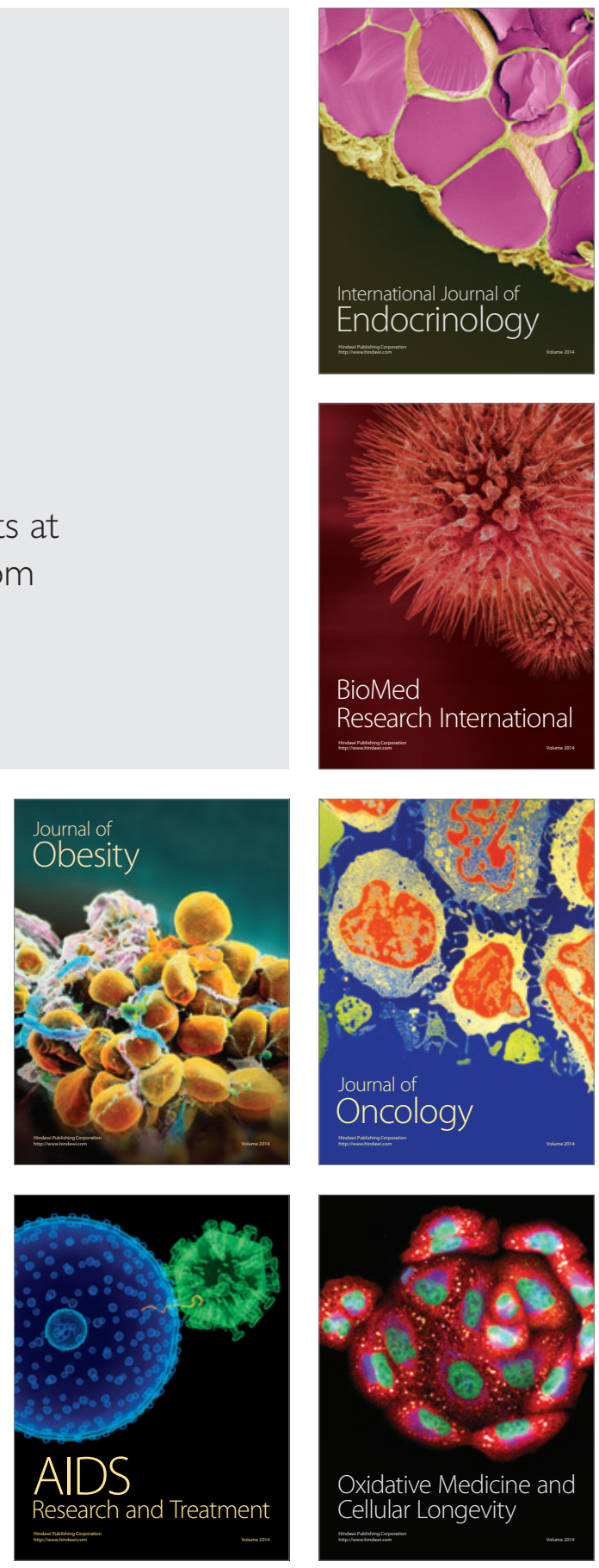